\title{
Reproductive activity in males of Sceloporus variabilis: Little time to rest, long time to breed
}

\author{
Eric Peña-Herrera ${ }^{1}$ (D) | Maricela Villagrán-SantaCruz ${ }^{2} \quad$ Oswaldo Hernández-Gallegos ${ }^{3}$ (D) | \\ Justin L. Rheubert ${ }^{4}$ (i) | Kevin M. Gribbins ${ }^{5} \quad$ | Gisela Granados-González ${ }^{1}$ (D)
}

${ }^{1}$ Laboratorio de Morfofisiología de la Reproducción, Facultad de Ciencias, Universidad Autónoma del Estado de México, Toluca, Estado de México,

México

${ }^{2}$ Laboratorio de Biología Tisular y Reproductora, Departamento de Biología Comparada, Facultad de Ciencias, Universidad Nacional Autónoma de México, Ciudad de México, México

${ }^{3}$ Laboratorio de Herpetología, Facultad de Ciencias, Universidad Autónoma del Estado de México, Toluca, Estado de México, México

${ }^{4}$ Department of Biology, University of Findlay, Findlay, Ohio

${ }^{5}$ Department of Biology, University of Indianapolis, Indianapolis, Indiana

\section{Correspondence}

Gisela Granados-González, Laboratorio de Morfofisiología de la Reproducción, Facultad de Ciencias, Universidad Autónoma del Estado de México, Toluca, Estado de México, México.

Email: ggranadosg@uaemex.mx

Funding information

Consejo Nacional de Ciencia y Tecnología (CONACyT)

\begin{abstract}
The reproductive activity of reptiles is typically assessed using monthly sampling. The spermatogenic cycle of Sceloporus variabilis was recently assessed using the aforementioned methodology, and only two spermatogenic phases (recrudescence and maximum activity) were observed. The authors hypothesized that quiescence and regression must occur in a short period (less than a month), which was not visualized by their monthly sampling methods. Thus, the entire spermatogenic cycle displayed by this species may have not been adequately represented. The present study assessed the spermatogenic cycle of $S$. variabilis in those months where the spermatogenic activity passes from maximum activity (July) to recrudescence (August) using weekly sampling to test the hypothesis that quiescence and regression do indeed occur. The results showed a regression period for 2 weeks, whereas quiescence was not observed. These results lead us to two hypotheses: (a) quiescence occurs in a very short period (days/hours) or (b) does not occur in this species. The data generated in this study suggest that species exhibiting rapid changes in spermatogenic activity need to be assessed at more frequent intervals to accurately depict the spermatogenic stages.
\end{abstract}

\section{K E Y W O R D S}

histology, lizard, reproduction, testis

\section{1 | INTRODUCTION}

In reptiles, variations have been observed in reproductive patterns (seasonal or continuous) with differences in length and timing in which the phases that comprise these cycles are carried out (James \& Shine, 1985; Méndez-de la Cruz, Manríquez-Morán, Arenas-Ríos, \& Ibargüengoytía, 2015; Rheubert et al., 2014; Shanbhag, 2002). The spermatogenic cycle is typically divided into four phases: (a) quiescence is characterized by a reduced germinal epithelium that only contains spermatogonia and Sertoli cells, the epididymis is devoid of sperm (Gribbins, 2011; Méndez-de la Cruz, Villagrán-Santa Cruz, López-Ortíz, \& Hernández-Gallegos, 2013; Villagrán-Santa Cruz, Hernández-Gallegos, \& Méndez-de la Cruz, 2009); (b) recrudescence is a period with a proliferation of spermatogonia and presence of spermatocytes I and II, the epididymis remains devoid of sperm (Al-Amri et al., 2013; Licht, 1984); (c) maximum activity involves spermatids dominating the germinal epithelium and sperm in the lumen of the seminiferous tubules, the epididymis is filled with mature sperm (Gribbins, 2011; Méndez-de la Cruz et al., 2013); 
and (d) regression, where there are no new generations of germ cells, the number of spermatocytes I, II, and spermatids decrease, and sperm debris are present in the lumina of seminiferous tubules, the epididymis is still filled with mature sperm (Hernández-Gallegos et al., 2014; Lozano, Uribe, \& Ramírez-Bautista, 2015).

Recent evidence highlights the use of histology as an essential component to accurately describe the reproductive activity, thus it is imperative to use both macroscopic and histological data (Granados-González et al., 2017; Gribbins et al., 2011; Méndez-de la Cruz et al., 2013; VillagránSanta Cruz et al., 2009). Omission of histological data may lead to inaccurate conclusions concerning length and timing of each phase of the spermatogenic cycle (Guillette \& Méndez-de la Cruz, 1993; Lee, Clayton, Eisenstein, \& Perez, 1989; Ramírez-Bautista, García-Collazo, \& Guillette, 2006; Ramírez-Bautista, Vitt, Ramírez-Hernández, MendozaQuijano, \& Smith, 2008).

With exceptions of a few studies in which collections are made every 15 days (Amat, Llorente, \& Carretero, 2000; Krohmer, Grassman, \& Crews, 1987; Roig, Carretero, \& Llorente, 2000), historically studies concerning reproductive cycles of reptiles have been completed using monthly samples (Cree, Cockrem, \& Guillette, 1992; GranadosGonzález et al., 2015; Gribbins, Rheubert, Collier, Siegel, \& Sever, 2008; Lance, 1989; Méndez-de la Cruz et al., 2013; Rostal, Lance, Grumbles, \& Alberts, 1994). This methodology has sufficed thus far, because changes in spermatogenic activity tend to be slow and all stages are observed (i.e., transition from one phase to other usually takes at least 1 month; Goldberg, 1974; Goldberg \& Parker, 1975; Hernández-Gallegos et al., 2014; Rheubert et al., 2009). However, Granados-González et al. (2017) described the spermatogenic cycle of Sceloporus variabilis from a population of Los Tuxtlas, Veracruz, Mexico, and described an atypical seasonal reproductive cycle, with a period of recrudescence of 2 months (August and September), a transitional period from recrudescence to maximum activity for 1 month (October), and a period of maximum spermatogenic activity for 9 months (November to July). Quiescence and regression were not observed within their monthly samples.

Based on their available data, Granados-González et al. (2017) hypothesized that quiescence and regression could occur in a period shorter than time between samplings. Therefore, the goal of this study is to test the hypothesis that both quiescence and regression do occur in the population of S. variabilis from Los Tuxtlas, Veracruz, Mexico, using histological evidence along with weekly sampling. Furthermore, the data provided here assess spermatogenic activity at more frequent intervals and provide insights into the relative timing of these limited stages and how reproductive cycles vary amongst taxa.

\section{2 | MATERIAL AND METHODS}

\section{1 | Animal collection}

Three adult males of $S$. variabilis were collected weekly between July 11 and August 15, 2016 (Scientific Collector Permit SEMARNAT FAUT 0186) at Catemaco (Los Tuxtlas), Veracruz, Mexico $\left(18.44100^{\circ} \mathrm{N}, 94.96440^{\circ} \mathrm{W}\right.$; \pm 170 masl; Granados-González et al., 2017 for description of study site). These months correspond with the ending of maximum activity in July and the beginning of recrudescence in August (Granados-González et al., 2017). The specimens were sacrificed using an intracoelomic injection of sodium pentobarbital (10\%). For each male the snoutvent length (SVL; nearest $1.0 \mathrm{~mm}$ ), weight (nearest $0.5 \mathrm{~g}$ ) and testis mass (TM; nearest $0.0001 \mathrm{~g}$ ) were recorded. Males were fixed in 10\% formaldehyde, preserved in $70 \%$ ethanol, and deposited in the Laboratorio de Herpetología, Facultad de Ciencias, Universidad Autónoma del Estado de México.

\section{2 | Histological procedures}

The right gonad was selected for the histological treatment and samples were processed according to standard histological techniques (gradual dehydration in ethanol, cleared in xylene, and embedded in Paraplast). Tissues were sectioned at $5 \mu \mathrm{m}$ with a rotary microtome and stained with haematoxylin-eosin for general cytology. Spermatogenic phases were assigned depending on germinal cells present in seminiferous tubules (Gribbins et al., 2008; Rheubert et al., 2014). Quantitatively the presence of sperm within both seminiferous tubules and epididymis were assessed, according to classification criteria of previous studies (GranadosGonzález et al., 2015, 2017; Hernández-Gallegos et al., 2014). Moreover, the diameter of seminiferous tubules (DST), seminiferous epithelial height (SEH), diameter of epididymal ducts (DED), and epididymal epithelial height (EEH) were measured within 25 microscopic fields per male.

\section{3 | Statistical procedures}

Assumptions of normality and homoscedasticity for SVL, TM, DST, SEH, DED and EEH were assessed via the Kolmogorov-Smirnov test and the Levene test, respectively. Although the lizards were collected weekly (6 weeks), statistical analysis was performed with data grouped biweekly (three biweek groups) because incongruence between metrics and histological data identified a highly probable type error II. We used an ANCOVA on testis mass and histological data with SVL as a covariate, 

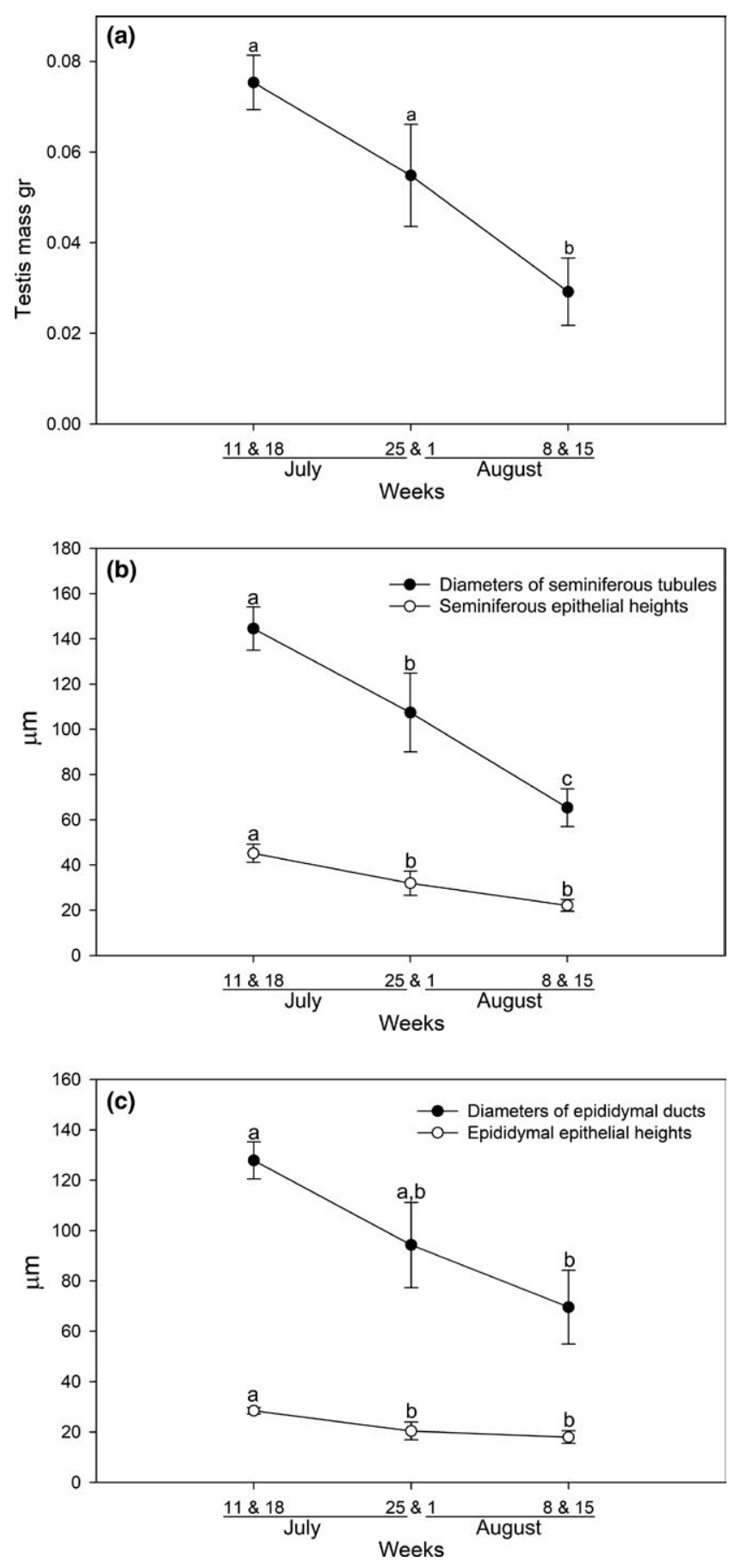

F I G URE 1 Biweekly variation in means of different reproductive characters of adult males of Sceloporus variabilis from Los Tuxtlas, Veracruz. (a) testis mass; (b) diameters of seminiferous tubules and seminiferous epithelial heights; (c) diameters of epididymal ducts and epididymal epithelial heights. Different letters above values indicate significant differences $(p<0.05)$. Vertical bars indicate $S E$

to test if there were differences between biweeks, followed by a multiple comparison tests (Duncan test) to identify where the differences exist. Analyses were performed in Statgraphics Centurion XVI, and the significance level was set at $p<0.05$.

\section{3 | RESULTS}

\subsection{Biweekly variation in testis mass and histological traits}

The average SVL was $65.2 \mathrm{~mm}$ (range $54.3-70.8 \mathrm{~mm}$, $n=18)$. The normality $(p>0.05)$ and homoscedasticity $(p>0.05)$ assumptions were met for TM and the histological values. There were significant differences between biweeks for all variables ( $p<0.05$ for overall models) and SVL influenced TM and DED ( $p<0.05$ for both variables). The changes observed in TM, DST, SEH, DED and EEH were parallel, displaying a decreasing pattern from the initial to the last biweekly sample (Figure 1a-c). Those quantitative changes were the result of changes in spermatogenic activity, as the amount of sperm present in the seminiferous tubules and epididymis gradually decreased (Figure 2a-f, Ms, Eps). Additionally, there was an absence of mature sperm in the seminiferous tubular lumen, and decrease in overall seminiferous diameter and seminiferous epithelial heights in the last biweek (Figure 1b).

\section{2 $\quad$ Spermatogenic activity}

Three phases of spermatogenic activity were identified using weekly analysis of testicular/epididymal histology: maximum activity, regression and recrudescence (Figure 2a,c,e). Maximum activity was present for 5 weeks (July 11 to August 8; Figure 3) and registered the highest values for TM $(0.075 \mathrm{~g})$, DST $(144.4 \mu \mathrm{m})$, SEH $(45.1 \mu \mathrm{m})$, DED $(127.6 \mu \mathrm{m})$ and EEH $(28.4 \mu \mathrm{m})$ in the initial 2 weeks (the first biweek group). In this phase, primary and secondary spermatocytes and mainly spermatids dominated the seminiferous epithelium (Figure $2 \mathrm{a}, 1^{\circ} \mathrm{sp}, 2^{\circ} \mathrm{sp}, \mathrm{Spt}$ ). Additionally, sperm was present in the lumina of seminiferous tubules and epididymides (Figure 2a,b, Ms, Eps). As the first phase progressed, the number of males showing spermiogenesis as the major phase within the testis were gradually decreased through the latter weeks of this phase, i.e., in the first 2 weeks (July 11 and 18), 100\% of lizards were spermiogenic. Later, during the third and fourth week (July 25 and August 1) the percentage of males decreased to $66 \%$ and in the fifth week (August 8), to $33 \%$. In the sixth week (August 15), no males in spermiogenesis were observed (Figure 3).

Regression was observed during 2 weeks (August 1 and 8, Figure 3), affecting the values of TM $(0.053 \mathrm{~g})$, DST $(106.1 \mu \mathrm{m})$, SEH $(31.5 \mu \mathrm{m})$, DED $(92.2 \mu \mathrm{m})$ and EEH $(20.1 \mu \mathrm{m})$ in the second biweek group. This phase was characterized by a seminiferous epithelium reduced only with spermatogonia and secondary spermatocytes (Figure 2c, $\mathrm{Sg}, 2^{\circ} \mathrm{sp}$ ). Remnant sperm was found in both seminiferous tubules and epididymides and there was no cell proliferation 

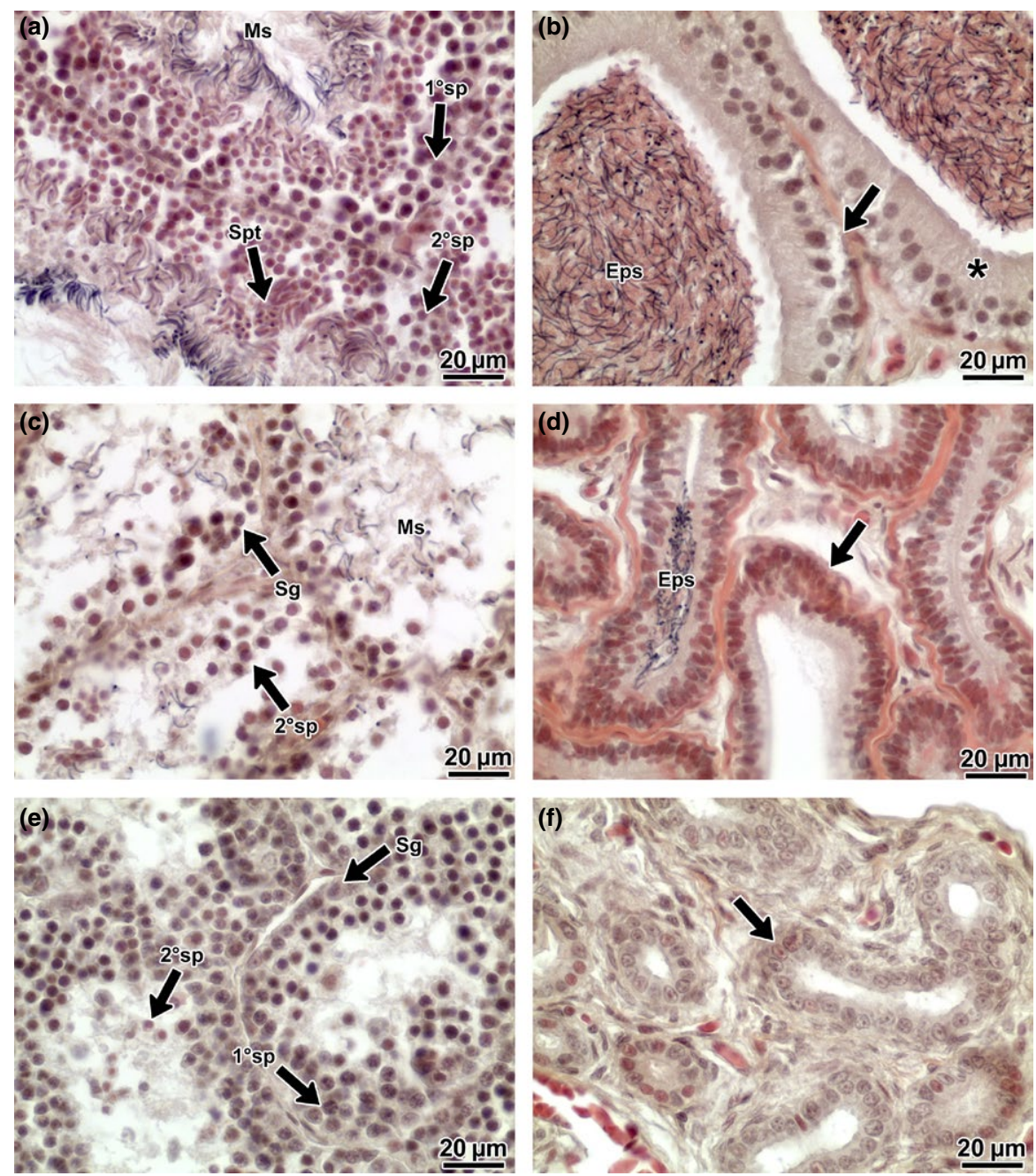

F I G U RE 2 Testicular and epididymal histology of Sceloporus variabilis from Los Tuxtlas, Veracruz. The spermatogenic phases are displayed in the order in which were registered. (a) maximum testicular activity and (b) epididymis filled with mature sperm; (c) regression and (d) epididymis with a few mature sperm; (e) recrudescence and (f) epididymis devoid of sperm. Sg, spermatogonia; $1^{\circ}$ sp, primary spermatocyte; $2^{\circ}$ sp, secondary spermatocyte; Spt, spermatid; Ms, mature sperm; Eps, epididymal sperm; black arrow, epididymal epithelium; *Epididymal epithelial cells filled with secretory material

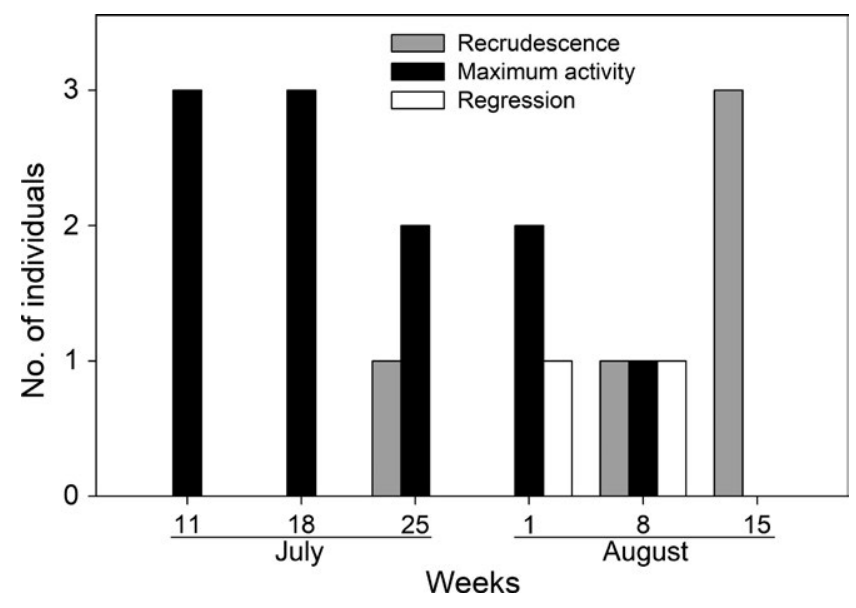

F I G URE 3 Graphical representation about frequency of adult males of Sceloporus variabilis from Los Tuxtlas, Veracruz, collected per week and their spermatogenic phase presented at that moment
(Figure 2c,d, Ms, Eps). Moreover, it is necessary to mention that only two males (one per week) of the total sample were found in regression (Figure 3), highlighting the male of the fourth week (August 1) that presented very late regression traits such as no spermiogenesis, few remnant sperm, cytoplasmic debris in the lumen, no cell proliferation and only spermatogonia at rest (non-mitotic).

Recrudescence was observed in the third (July 25), fifth (August 8) and sixth week (August 15, Figure 3), reflecting in the values of TM $(0.03 \mathrm{~g})$, DST $(66.8 \mu \mathrm{m})$, SEH $(22.7 \mu \mathrm{m})$, $\operatorname{DED}(71.9 \mu \mathrm{m})$ and $\operatorname{EEH}(18.3 \mu \mathrm{m})$ for the last biweek group. During this phase there was a marked increase in cell proliferation as the seminiferous epithelium was dominated by primary spermatocytes, although spermatogonia and secondary spermatocytes were observed in smaller numbers (Figure 2e, $\left.\mathrm{Sg}, 1^{\circ} \mathrm{sp}, 2^{\circ} \mathrm{sp}\right)$. Sperm was not observed within the lumina of seminiferous tubules and epididymides at this time. The 
tubular diameter and epididymal ducts remained reduced (Figure 2e,f). Unlike the decreasing pattern of maximum activity, recrudescence had an increasing pattern, as in the third week (July 25) and fifth week (August 8), only 33\% of males were in recrudescence, whereas in the sixth week (August 15) $100 \%$ of males were in recrudescence (Figure 3). Finally, no males were observed in a quiescent state in which the seminiferous tubules would have only contained spermatogonia and the epididymides devoid of sperm.

\section{DISCUSSION}

The reproductive activity observed in this study does not differ in the beginning (July) and the end (August) to that reported by Granados-González et al. (2017). Although, Granados-González et al. (2017) only found two spermatogenic phases (recrudescence and maximum activity), this study observed a third phase, regression, which occurred for 2 weeks (August 1 and 8). Although a quiescence phase was not observed, this phase could occur within a few days/hours (between August 8 and 15). Evidence that may support the existence of quiescence, is the male in very late regression of the fourth week (August 1). This individual was classified in a very late regression instead of quiescence because despite having seminiferous tubules only with spermatogonia and no cell proliferation (like in quiescence), they still contained cytoplasmic debris (sign of a recent spermiation; Ferreira, Laura, \& Dolder, 2002) and a few remnant sperm (which are not observed in quiescence; Licht, 1967) in the lumina, suggesting that this male was in a final step of regression and preparing to enter to quiescence. Another possibility is that quiescence (if present) and regression do not occur at the population level due to the briefness in which they occur (2 weeks or less). For example, Licht (1984) stated that Homalopsis buccata may exhibit continuous spermatogenesis at the population level but not individually due to the presence of males with a pronounced spermatogenic cycle (individual males may be at different stages of the spermatogenic cycle during a given time period).

Gathering information from both studies (GranadosGonzález et al., 2017; this study), S. variabilis has a reproductive cycle with a recrudescence period for 1 month and 3 weeks, a transitional period from recrudescence to maximum activity for 1 month, a maximum activity period for 9 months and 2 weeks, and a regression period for 2 weeks, where there is an overlap between these phases, i.e., spermatogenic variation within individuals in 3 weeks to early August. The length and speed of regression and a small and variable quiescence period in this study are evidence that basic histology provides invaluable information about spermatogenic activity that quantitative data alone would never provide to a basic study on sperm development in vertebrates.
Also, it may be necessary to sample in shorter intervals when stages of the spermatogenic cycle are not observed monthly within a taxon of reptile. This was the case of S. variabilis, where regression was only observed during weekly samples.

Individual variation in the spermatogenic activity of S. variabilis has not been previously documented (GarcíaCollazo, 1996; Granados-González et al., 2017), and it was observed in three of the 6 weeks of this study. This may be due to the fact that some females are still in the last phases of vitellogenesis in August (Benabib, 1994; Cruz-Elizalde \& Ramírez-Bautista, 2016), the same month where the last reproductively active males are observed (until August 8). Therefore, it is possible that plasticity in the spermatogenic cycle allows males to extend their spermatogenic activity and thus maintain sperm production for possible late ovulating females. A similar pattern was observed in the snake H. buccata, where males in the spermiogenic phase, recrudescence and regression were all observed in histological samples from the same time within any month of the year, but the spermatogenic variation was highest during the female reproductive peak (Berry \& Lim, 1967). Furthermore, intrapopulational spermatogenic variation has been observed in other species of Sceloporus (Rheubert et al., 2014).

It is interesting to note that the recrudescent male of the third week (July 25) was the smallest male of the study samples $(54.3 \mathrm{~mm} \mathrm{SVL})$. A maximum activity period shorter than the other males (finishing before time the spermatogenic cycle of the season and thus it was starting a new spermatogenic cycle before all the other males) may favour other physiological processes such as body growth, which may be necessary to compete against other males. Furthermore, testosterone, which is associated with spermiogenic activity (Chamut, Jahn, Arce, \& Manes, 2012), has been reported to conceivably inhibit growth in lizards (Cox \& John-Alder, 2005).

According to reconstructions of ancestral states (Méndezde la Cruz et al., 2015; Rheubert et al., 2014), the genus Sceloporus has an ancestral spring reproductive cycle where fall reproductive cycles have evolved numerous times. Also, three reproductive patterns have been registered in genus Sceloporus: spring spermatogenesis (Goldberg, 1971; Méndez-de la Cruz, Guillette, Villagrán-Santa Cruz, \& Casas-Andreu, 1988), fall spermatogenesis (Guillette \& Méndez-de la Cruz, 1993; Rheubert et al., 2014) and continuous spermatogenesis (Hernández-Gallegos, Méndez-de la Cruz, Villagrán-Santa Cruz, \& Andrews, 2002; Lozano et al., 2015). Based on this classification, and reproductive studies without histological data (Benabib, 1994; Ramírez-Bautista et al., 2006) the spermatogenic cycle of S. variabilis was grouped in the fall pattern (Rheubert et al., 2014). Currently, we know that it cannot be classified within any pattern since male reproductive period is exceptionally long ( 9 months and 2 weeks, Granados-González et al., 2017; this study), 
involving the four seasons but not enough to become a continuous spermatogenesis. Rheubert et al. (2014) stated that spermatogenic cycles evolved to start recrudescence earlier. Thereby, an earlier recrudescence and an extended maximum activity period in $S$. variabilis may result in a shorter regression, which was recorded for 2 weeks in this study. Besides, we cannot discard the possibility concerning an extended spermatogenic cycle and its consequent evolution to a continuous cycle, since it may evolve from either a fall or spring spermatogenic cycle. For example, the continuous cycle of Sceloporus bicanthalis (Hernández-Gallegos et al., 2002) potentially evolved from a fall ancestral cycle, which is similar to the cycle of Sceloporus scalaris (Newlin, 1976); whereas, the continuous cycle of Sceloporus grammicus (Lozano et al., 2015) most likely evolved from a spring spermatogenic cycle (Rheubert et al., 2014). Either way, more studies involving species with extended spermatogenic cycles are necessary to fully understand the mechanisms involved in the evolution of these extended cycles. Furthermore, variation at the populational levels may provide insights into potential abiotic (such as temperature, altitude, and rainfall; Colli, 1991; Goldberg, 1974; Licht, 1971) and biotic factors (such as presence of receptive females; Fernández, Medina, Kubisch, Scolaro, \& Ibargüengoytía, 2017; Hernández-Gallegos et al., 2002; Wiederhecker, Pinto, \& Colli, 2002) affecting spermatogenesis. For example, the extended period spermatogenesis in S. variabilis is similar between populations (García-Collazo, 1996; Granados-González et al., 2017), whereas spermatogenesis of S. grammicus (Lozano et al., 2015) and Sceloporus mucronatus (Villagrán-Santa Cruz et al., 2009) differ at the populational level. Observations concerning similarities and differences of various reproductive strategies are necessary to determine potential underlying causes of variation (or the lack thereof).

One aspect typically not considered during explanation of variation in reproductive cycles is mortality. Peña-Herrera (unpublished data) estimated the age of adult males of S. variabilis from the same population used in this study. The average age was 1.6 years with a maximum age of 3 years, where only $11 \%$ of adult males from total sample reached the latter age. These data corroborate findings by Fitch (1973) on a population in Costa Rica, suggesting that $S$. variabilis is a species with a high mortality rate. The high mortality may have led to $S$. variabilis having a very long reproductive cycle (leading to an increase in fecundity), as a low life expectancy is typical of tropical species with continuous reproduction (Tinkle, 1969). Therefore, if we consider the average age (1.6 years) for adult males of $S$. variabilis as life expectancy, it would be expected that lizards with a shorter life expectancy had a longer reproductive period and an earlier maturity (either in age or body size). This is the case of the temperate lizard S. bicanthalis, which has a lower life expectancy (1.3 years; Rodríguez-Romero et al., 2011) than
S. variabilis, reflected in a maturity at a smaller size $(34 \mathrm{~mm}$ SVL vs. $51 \mathrm{~mm}$ SVL of S. variabilis; Granados-González et al., 2017; Gribbins et al., 2011) and in a longer reproductive period (continuous spermatogenesis, Hernández-Gallegos et al., 2002, Gribbins et al., 2011).

Additionally, when we consider data about maximum (3 years) and average (1.6 years) age, age at sexual maturity (4 months, Benabib, 1994) and a prolonged reproductive cycle (9 months and 2 weeks) for $S$. variabilis, it may be argued that males in this study were at least in their first reproductive season and those which had an age of 3 years were potentially in their fourth reproductive season, considering that hatchlings born at the beginning of the reproductive season can breed at the end of that same reproductive season (Benabib, 1994). Data concerning mortality and average age for females in this study population is currently not available.

All these factors: phylogenetic effects, a seasonal reproductive cycle with a length that is maintained in any environment, the availability of receptive females almost all year round and a high mortality rate may be the mechanisms that are causing the reproductive cycle of male $S$. variabilis to be extended. Thus, these types of phylogenetic and biotic selective pressures could be involved in the transition from a seasonal to continuous reproductive cycle in the future of this species. This study supports the claim by Rheubert et al. (2014) that environmental factors are not the only selection pressure regulating the reproductive activity in males.

\section{ACKNOWLEDGEMENTS}

We would like to thank the community of the Ejido Adolfo López Mateos, Selva del Marinero, for aiding in the collection of lizards and to the Consejo Nacional de Ciencia y Tecnología (CONACyT) for its financial support to PeñaHerrera E.

\section{ORCID}

Eric Peña-Herrera (D) http://orcid.org/0000-0001-5015-7354 Oswaldo Hernández-Gallegos (D) http://orcid. org/0000-0002-7850-3033

Justin L. Rheubert (D) http://orcid.org/0000-0002-6354-7164 Gisela Granados-González (iD http://orcid. org/0000-0002-4664-1431

\section{REFERENCES}

Al-Amri, I. S., Mahmoud, I. Y., Waring, C. P., Alkindi, A. Y., Khan, T., Bakheit, C., \& Al-Mawali, K. M. (2013). The reproductive cycle of the male house gecko, Hemidactylus flaviviridis, in relation to plasma steroid concentrations, receptors, and steroidogenic ultrastuctural 
features, in Oman. General and Comparative Endocrinology, 187, 23-31. https://doi.org/10.1016/j.ygcen.2013.02.040

Amat, F., Llorente, G. A., \& Carretero, M. A. (2000). Reproductive cycle of the sand lizard (Lacerta agilis) in its southwestern range. AmphibiaReptilia, 21, 463-476. https://doi.org/10.1163/156853800300059340

Benabib, M. (1994). Reproduction and lipid utilization of tropical populations of Sceloporus variabilis. Herpetological Monographs, 8, 160-180. https://doi.org/10.2307/1467079

Berry, P. Y., \& Lim, G. S. (1967). The breeding pattern of the PuffFaced Water Snake, Homalopsis buccata Boulenger. Copeia, 1967, 307-313. https://doi.org/10.2307/1442118

Chamut, S., Jahn, G. A., Arce, O. E. A., \& Manes, M. E. (2012). Testosterone and reproductive activity in the male tegu lizard, Tupinambis merianae. Herpetological Conservation and Biology, 7, 299-305.

Colli, G. R. (1991). Reproductive ecology of Ameiva ameiva (Sauria, Teiidae) in the Cerrado of Central Brazil. Copeia, 1991, 1002-1012. https://doi.org/10.2307/1446095

Cox, R. M., \& John-Alder, H. B. (2005). Testosterone has opposite effects on male growth in lizards (Sceloporus spp.) with opposite patterns of sexual size dimorphism. Journal of Experimental Biology, 208, 4679-4687. https://doi.org/10.1242/jeb.01948

Cree, A., Cockrem, J. F., \& Guillette, L. J. Jr (1992). Reproductive cycles of male and female tuatara (Sphenodon punctatus) on Stephens Island, New Zealand. Journal of Zoology, 226, 199-217. https://doi. org/10.1111/j.1469-7998.1992.tb03834.x

Cruz-Elizalde, R., \& Ramírez-Bautista, A. (2016). Reproductive cycles and reproductive strategies among populations of the Rose-bellied Lizard Sceloporus variabilis (Squamata: Phrynosomatidae) from central Mexico. Ecology and Evolution, 6, 1753-1768. https://doi. org/10.1002/ece3.1998

Fernández, J. B., Medina, M., Kubisch, E. L., Scolaro, J. A., \& Ibargüengoytía, N. R. (2017). Reproductive strategies in males of the world's southernmost lizards. Integrative Zoology, 12, 132-147. https://doi.org/10.1111/1749-4877.12224

Ferreira, A., Laura, I. A., \& Dolder, H. (2002). Reproductive cycle of male green iguanas, Iguana iguana (Reptilia: Sauria: Iguanidae), in the Pantanal Region of Brazil. Journal of Morphological Science, 19(1), 23-28.

Fitch, H. S. (1973). Population structure and survivorship in some Costa Rica Lizards. Lawrence, KS: Museum of Nature History, University of Kansas.

García-Collazo, R. (1996). Espermatogénesis en dos poblaciones (semidesértica y subtropical) de Sceloporus variabilis variabilis, Unpublished master thesis. Universidad Nacional Autónoma de México, Mexico.

Goldberg, S. R. (1971). Reproductive cycle of the ovoviviparous iguanid lizard Sceloporus jarrovi Cope. Herpetologica, 27, 123-131.

Goldberg, S. R. (1974). Reproduction in mountain and lowland populations of the lizard Sceloporus occidentalis. Copeia, 1974, 176-182. https://doi.org/10.2307/1443021

Goldberg, S. R., \& Parker, W. S. (1975). Seasonal testicular histology of the colubrid snakes, Masticophis taeniatus and Pituophis melanoleucus. Herpetologica, 31, 317-322.

Granados-González, G., Rheubert, J. L., Villagrán-Santa Cruz, M., González-Herrera, M. E., Dávila-Cedillo, J. V., Gribbins, K. M., \& Hernández-Gallegos, O. (2015). Male reproductive cycle in Aspidoscelis costata costata (Squamata: Teiidae) from Tonatico, Estado de México, México. Acta Zoologica, 96, 108-116. https:// doi.org/10.1111/azo.12057
Granados-González, G., Villagrán-Santa Cruz, M., Peña-Herrera, E., Rheubert, J. L., Gribbins, K. M., \& Hernández-Gallegos, O. (2017). Spermatogenesis in Sceloporus variabilis (Squamata, Phrynosomatidae): A non-quiescent pattern. Acta Zoologica, 2017, 1-10. https://doi.org/10.1111/azo.12229

Gribbins, K. M. (2011). Reptilian spermatogenesis: A histological and ultrastructural perspective. Spermatogenesis, 1, 250-269. https:// doi.org/10.4161/spmg.1.3.18092

Gribbins, K. M., Anzalone, M., Collier, M., Granados-González, G., Villagrán-Santa Cruz, M., \& Hernández-Gallegos, O. (2011). Temporal germ cell development strategy during continuous spermatogenesis within the montane lizard, Sceloporus bicanthalis (Squamata; Phrynosomatidae). Theriogenology, 76, 1090-1099. https://doi.org/10.1016/j.theriogenology.2011.05.015

Gribbins, K. M., Rheubert, J. L., Collier, M. H., Siegel, D. S., \& Sever, D. M. (2008). Histological analysis of spermatogenesis and the germ cell development strategy within the testis of the male Western Cottonmouth Snake, Agkistrodon piscivorus leucostoma. Annals of Anatomy, 190, 461-476. https://doi.org/10.1016/j.aanat.2008.07.003

Guillette, L. J. Jr, \& Méndez-de la Cruz, F. R. (1993). The reproductive cycle of the viviparous Mexican lizard Sceloporus torquatus. Journal of Herpetology, 27, 168-174. https://doi.org/10.2307/1564933

Hernández-Gallegos, O., Méndez-de la Cruz, F. R., Villagrán-Santa Cruz, M., \& Andrews, R. M. (2002). Continuous spermatogenesis in the lizard Sceloporus bicanthalis (Sauria: Phrynosomatidae) from high elevation habitat of central Mexico. Herpetologica, 58, 415-421. https://doi.org/10.1655/00180831(2002) 058[0415:CSITLS]2.0.CO;2

Hernández-Gallegos, O., Méndez-de la Cruz, F. R., Villagrán-Santa Cruz, M., Rheubert, J. L., Granados-González, G., \& Gribbins, K. M. (2014). Seasonal spermatogenesis in the Mexican endemic oviparous lizard, Sceloporus aeneus (Squamata: Phrynosomatidae). Spermatogenesis, 4(3), 1-8. https://doi.org/10.4161/21565562.2014 .988585

James, C., \& Shine, R. (1985). The seasonal timing of reproduction: A tropical-temperate comparison in Australian lizards. Oecologia, 67, 464-474. https://doi.org/10.1007/BF00790016

Krohmer, R. W., Grassman, M., \& Crews, D. (1987). Annual reproductive cycle in the male red-sided garter snake, Thamnophis sirtalis parietalis: Field and laboratory studies. General and Comparative Endocrinology, 68, 64-75. https://doi. org/10.1016/0016-6480(87)90061-X

Lance, V. A. (1989). Reproductive cycle of the American alligator. American Zoologist, 29, 999-1018. https://doi.org/10.1093/ icb/29.3.999

Lee, J. C., Clayton, D., Eisenstein, S., \& Perez, I. (1989). The reproductive cycle of Anolis sagrei in Southern Florida. Copeia, 1989, 930-937. https://doi.org/10.2307/1445979

Licht, P. (1967). Environmental control of annual testicular cycles in the lizard Anolis carolinensis. I. Interaction of light and temperature in the initiation of testicular recrudescence. Journal of Experimental Zoology, 165, 505-516. https://doi.org/10.1002/jez.1401650317

Licht, P. (1971). Regulation of the annual testis cycle by photoperiod and temperature in the lizard Anolis carolinensis. Ecology, 52, 240252. https://doi.org/10.2307/1934582

Licht, P. (1984). Reptiles. In G. E. Lamming (Ed.), Marshall's physiology of reproduction: Reproductive cycle of vertebrates (pp. 206282). New York, NY: Churchill Livingstone.

Lozano, A., Uribe, M. C., \& Ramírez-Bautista, A. (2015). Seasonal and continuous spermatogenesis in the viviparous lizard Sceloporus 
grammicus, a study of two populations in contrasting environments from Central Mexican Plateau. Zoologischer Anzeiger, 254, 72-85. https://doi.org/10.1016/j.jcz.2014.12.001

Méndez-de la Cruz, F. R., Guillette, L. J. Jr, Villagrán-Santa Cruz, M., \& Casas-Andreu, G. (1988). Reproductive and fat body cycle of the viviparous lizard, Sceloporus mucronatus (Sauria: Iguanidae). Journal of Herpetology, 22(1), 1-12. https://doi.org/10.2307/1564351

Méndez-de la Cruz, F. R., Manríquez-Morán, N. L., Arenas-Ríos, E., \& Ibargüengoytía, N. (2015). Male reproductive cycles in lizards. In J. L. Rheubert, D. S. Siegel, \& S. E. Trauth (Eds.), Reproductive biology and phylogeny of lizards and tuatara (pp. 302-339). Boca Raton, FL: CRC Press.

Méndez-de la Cruz, F. R., Villagrán-Santa Cruz, M., López-Ortíz, M. L., \& Hernández-Gallegos, O. (2013). Reproductive cycle of a high- altitude oviparous lizard, Sceloporus spinosus (Reptilia: Phrynosomatidae). The Southwestern Naturalist, 58, 54-63. https:// doi.org/10.1894/0038-4909-58.1.54

Newlin, M. E. (1976). Reproduction in the bunch grass lizard, Sceloporus scalaris. Herpetologica, 32, 171-184.

Ramírez-Bautista, A., García-Collazo, R., \& Guillette, L. J. Jr (2006). Reproductive, fat, and liver cycles of male and female rose-bellied lizards, Sceloporus variabilis, from coastal areas of Southern Veracruz, Mexico. The Southwestern Naturalist, 51, 163-171. https:// doi.org/10.1894/0038-4909(2006) 51[163:RFALCO]2.0.CO;2

Ramírez-Bautista, A., Vitt, L. J., Ramírez-Hernández, A., MendozaQuijano, F., \& Smith, G. R. (2008). Reproduction and sexual dimorphism of Lepidophyma sylvaticum (Squamata:Xantusiidae), a tropical night lizard from Tlanchinol, Hidalgo, Mexico. Amphibia-Reptilia, 29, 207-216. https://doi.org/10.1163/156853808784124938

Rheubert, J. L., Poldemann, E. H., Eckstut, M. E., Collier, M. H., Sever, D. M., \& Gribbins, K. M. (2009). Temporal germ cell development strategy during mixed spermatogenesis within the male Mediterranean gecko, Hemidactylus turcicus (Reptilia: Gekkonidae). Copeia, 2009, 793-800. https://doi.org/10.1643/CG-09-034

Rheubert, J. L., Touzinsky, K. T., Sever, D. M., Aldridge, R. D., Wilmes, A. J., Siegel, D. S., \& Gribbins, K. M. (2014). Reproductive biology of Sceloporus consobrinus (Phrynosomatidae): Male germ cell development and reproductive cycle comparisons within spiny lizards. Journal of Herpetology, 48, 162-171. https://doi. org/10.1670/12-156
Rodríguez-Romero, F., Smith, G. R., Méndez-Sánchez, F., HernándezGallegos, O., Sánchez-Nava, P., \& Méndez-de la Cruz, F. R. (2011). Demography of a semelparous, high-elevation population of Sceloporus bicanthalis (Lacertilia: Phrynosomatidae) from the Nevado de Toluca Volcano, Mexico. The Southwestern Naturalist, 56, 71-77. https://doi.org/10.1894/GC-193.1

Roig, J. M., Carretero, M. A., \& Llorente, G. A. (2000). Reproductive cycle in a Pyrenean oviparous population of the common lizard (Zootoca vivipara). Netherlands Journal of Zoology, 50, 15-27. https://doi.org/10.1163/156854200505775

Rostal, D. C., Lance, V. A., Grumbles, J. S., \& Alberts, A. C. (1994). Seasonal reproductive cycle of the desert tortoise (Gopherus agassizii) in the Eastern Mojave Desert. Herpetological Monographs, 8 , 72-82. https://doi.org/10.2307/1467071

Shanbhag, B. (2002). Reproductive biology of Indian reptiles. Proceedings of the Indian National Science Academy, 68, 497-528.

Tinkle, D. W. (1969). The concept of reproductive effort and its relation to the evolution of life histories of lizards. The American Naturalist, 103, 501-516. https://doi.org/10.1086/282617

Villagrán-Santa Cruz, M., Hernández-Gallegos, O., \& Méndez-de la Cruz, F. R. (2009). Reproductive cycle of the lizard Sceloporus mucronatus with comments on intraspecific geographic variation. Western North American Naturalist, 69, 437-446. https://doi. org/10.3398/064.069.0403

Wiederhecker, H. C., Pinto, A. C. S., \& Colli, G. R. (2002). Reproductive ecology of Tropidurus torquatus (Squamata: Tropiduridae) in the highly seasonal Cerrado biome of central Brazil. Journal of Herpetology, 36, 82-91. https://doi.org/10.1670/0022-1511(2002) 036[0082:REOTTS]2.0.CO;2

How to cite this article: Peña-Herrera E, VillagránSantaCruz M, Hernández-Gallegos O, Rheubert JL, Gribbins KM, Granados-González G. Reproductive activity in males of Sceloporus variabilis: Little time to rest, long time to breed. Acta Zool. 2018;00:1-8. https://doi.org/10.1111/azo.12275 